\title{
Dyspnoea caused by a Chilaiditi syndrome: contribution of the non-invasive ventilation
}

\author{
Ahmed Belkouch, ${ }^{1,2}$ Abderrahim Htit, ${ }^{2}$ Saad Zidouh, ${ }^{2}$ Lahcen Belyamani ${ }^{2}$
}

${ }^{1}$ Hôpital Militaire d'Instruction Mohammed V, Rabat, Morocco ${ }^{2} E D$, Hôpital Militaire d'Instruction Mohammed V, Rabat, Morocco

\section{Correspondence to} Dr Ahmed Belkouch, belkouch1@gmail.com

\section{DESCRIPTION}

A 49-year-old man presented to the emergency department with respiratory distress and extreme abdominal distension, with a history of chronic

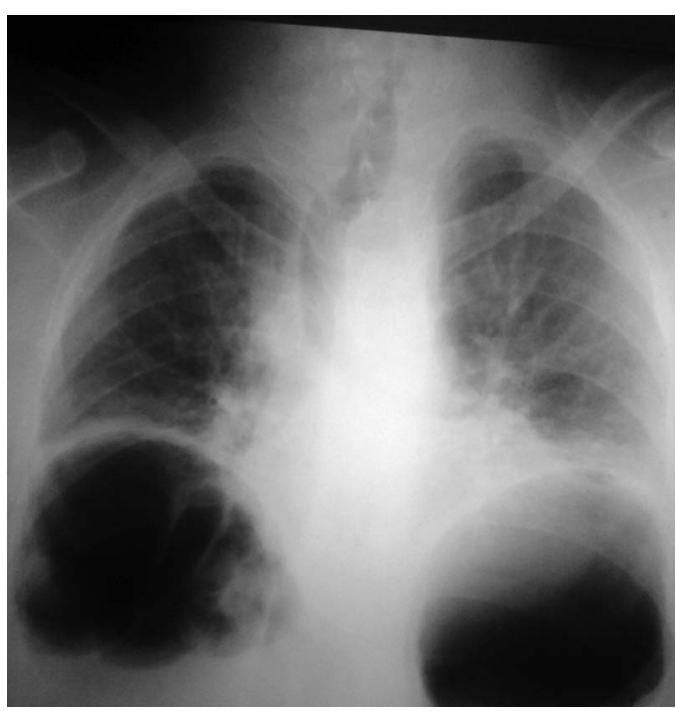

Figure 1 Chest radiograph showing the Chilaiditi sign. constipation. His chest auscultation was normal and the patient experienced drowsiness and showed signs of respiratory fatigue. He experienced severe disturbances in blood gas tensions $(\mathrm{pH} 7.28$, $\mathrm{PaO}_{2} 65 \mathrm{~mm} \mathrm{Hg}, \mathrm{PaCO}_{2} 76 \mathrm{~mm} \mathrm{Hg}$ ); the admission chest radiograph (figure 1 ) showed Chilaiditi sign and large colonic distension. The CT scan showed the same aspect with no complications (figure 2).

Non-invasive ventilation was performed $(100 \%$ $\mathrm{FiO}_{2}$, inspiratory pressure $=12 \pm 2 \mathrm{~cm} \mathrm{H}_{2} \mathrm{O}$, PEEP 5$8 \mathrm{~cm} \mathrm{H}_{2} \mathrm{O}$ ) with the establishment of a nasogastric suction probe and enema spillway; after $48 \mathrm{~h}$ the patient improved and was transferred to gastroenterology department to explore his colonic disorder.

The Chilaiditi sign was first described in 1910 by the radiologist Demetrius Chilaiditi. It is defined as colonic interposition between the liver and diaphragm (differential diagnosis of pneumoperitonium). ${ }^{1}$ It is called Chilaiditi syndrome when it is accompanied by clinical symptoms such as dyspnoea and cardiovascular manifestations (tachycardia, cardiac rhythm troubles and cardiac arrest) owing to the interposition of the large bowel between the liver and the diaphragm causing an increase in the thoracic pressure. ${ }^{2}$
To cite: Belkouch A, Htit A, Zidouh $\mathrm{S}$, et al. BMJ Case Rep Published online: [please include Day Month Year] doi:10.1136/bcr-2013010421

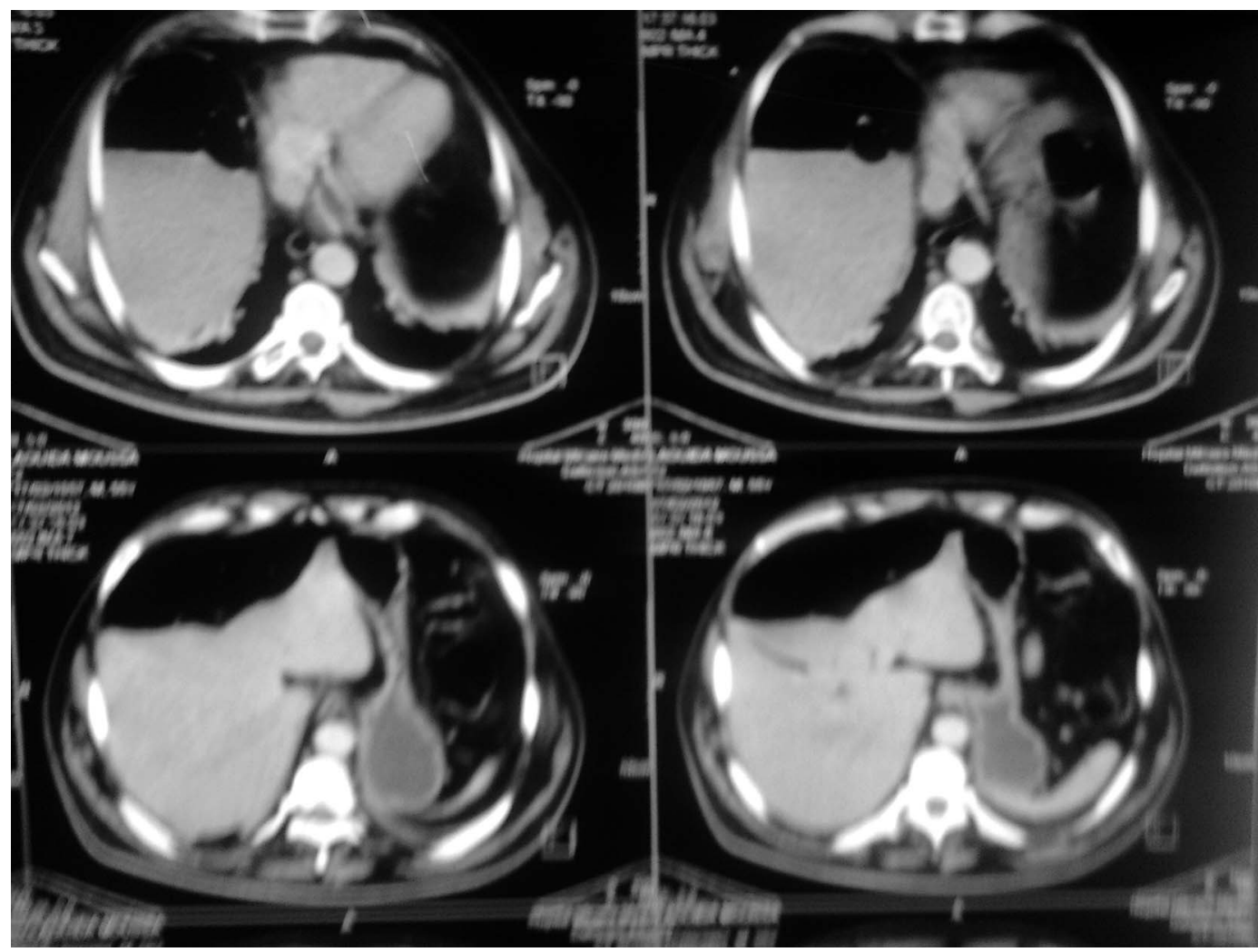

Figure 2 CT scan showing the same aspect of the Chilaiditi sign and the absence of complications. 


\section{Learning point}

The non-invasive ventilation can save the patient by avoiding invasive ventilation, providing positive expiratory pressure and decreasing respiratory load. It also allows reducing work of respiration and recruiting collapsed alveoli.
Competing interests None.

Patient consent Obtained.

Provenance and peer review Not commissioned; externally peer reviewed.

\section{REFERENCES}

1 Dogu F, Reisli I, Ikinciogullari A, et al. Unusual cause of respiratory distress: Chilaiditi syndrome. Pediatr Int 2004;46:188-90.

2 Messina M, Paolucci E, Casoni G, et al. A case of severe dyspnea and an unusual bronchoscopy: the Chilaiditi syndrome. Respiration 2008;76:216-7.

Copyright 2013 BMJ Publishing Group. All rights reserved. For permission to reuse any of this content visit http://group.bmi.com/group/rights-licensing/permissions.

BMJ Case Report Fellows may re-use this article for personal use and teaching without any further permission.

Become a Fellow of BMJ Case Reports today and you can:

- Submit as many cases as you like

- Enjoy fast sympathetic peer review and rapid publication of accepted articles

- Access all the published articles

- Re-use any of the published material for personal use and teaching without further permission

For information on Institutional Fellowships contact consortiasales@bmjgroup.com

Visit casereports.bmj.com for more articles like this and to become a Fellow 